\title{
A small RNA decreases the sensitivity of Shigella sonnei to norfloxacin
}

\author{
I-Ning Gan ${ }^{1}$ and Hock Siew Tan ${ }^{1,2^{*}}$ (D)
}

\begin{abstract}
Objectives: Shigella is a human pathogen that causes shigellosis, an acute invasive intestinal infection. Recent studies in the model bacterium Escherichia coli (E. coli) provided evidence that small regulatory RNAs (sRNAs) can contribute to antimicrobial resistance or susceptibility. One of the sRNAs is SdsR, which increases sensitivity of E. coli against fluoroquinolone by repressing the drug efflux pump, TolC. However, no reports exist about the effect of SdsR on fluoroquinolone resistance in Shigella sonnei (S. sonnei). In this study, we established the effect of SdsR on the sensitivity of S. sonnei to norfloxacin.

Data description: We tested the effects of SdsR and SdsRv2 on fluoroquinolone resistance in S. sonnei in vivo. SdsRv2 is a synthetic version which promotes higher binding stability to to/C mRNA. Overexpression of either SdsR or SdsRv2 lowers the expression of to/C mRNA. Interestingly, SdsR and SdsRv2 promote the growth of S. sonnei in the presence of a sub-inhibitory concentration of norfloxacin. Mutant carrying SdsRv2 showed the highest growth advantage. This phenotype is opposite to the effect of SdsR reported in E. coli. This study is an example that demonstrates the difference in the phenotypic effect of a highly conserved SRNA in two closely related bacteria.
\end{abstract}

Keywords: Small RNA, SdsR, Antibiotics resistance, Shigella sonnei, Norfloxacin, Fluoroquinolone

\section{Objective}

The predominant Shigella species worldwide is S. son$n e i$, a less virulent but widely distributed across developed countries [1]. In the two last decades, Shigella have acquired resistance to many antibiotics, prompting the World Health Organization to list Shigella as a pathogen which urgently needs new antibiotics. One of the mechanism is through active efflux of fluoroquinolones [2]. These efflux pumps export antibiotics that accumulate in the cell, which enables the bacteria to survive antibiotic treatment. Bacteria often employ sRNAs as a post-transcriptional regulator of gene expression in response to various environmental challenges such as $\mathrm{pH}$, temperature and antibiotics [3]. A sRNA known as SdsR regulates the expression of $\mathrm{TolC}$, an efflux pump that promotes resistance to fluoroquinolone, a commonly prescribed antibiotic used to treat bacterial infections [4]. In E. coli,

*Correspondence: tan.hocksiew@monash.edu

${ }^{1}$ School of Science, Monash University Malaysia, Jalan Lagoon Selatan, 47500 Subang Jaya, Selangor, Malaysia

Full list of author information is available at the end of the article overexpression of SdsR decreases mRNA and protein levels of TolC [4] leading to an increase in sensitivity to fluoroquinolones [5].

Although S. sonnei is a close phylogenetic relative of $E$. coli [6], it is not clear whether SdsR plays a similar role in S. sonnei. Given the high conservation of SdsR and its target $t o l C$ in both $E$. coli and $S$. sonnei, we postulated that SdsR might perform a similar function in S. sonnei. We further hypothesized that increasing the stability of the RNA-RNA complex between SdsR and tolC mRNA may lead to an increase in the susceptibility of $S$. sonnei to norfloxacin due to downregulation of tolC mRNA. This study aims to determine the efficacy of SdsR and SdsRv2 in reducing the antibiotics resistance in Shigella sonnei.

\section{Data description \\ Results}

To increase the stability of RNA-RNA complex between SdsR and $t o l C$, we incorporated four point mutations at the binding site of tolC in the design of SdsRv2 (Table 1, Data file 1). These mutations occurred in the predicted 
Table 1 Overview of data files

\begin{tabular}{llll}
\hline Label & Name of data file/data set & File types & Data repository and identifier \\
\hline Data file 1 [7] & Design of synthetic RNA, SdsRv2 & PDF & Figshare (https://doi.org/10.6084/m9.figshare.7429040) \\
Data file 2 [8] & Materials and method details & DOCX & Figshare (https://doi.org/10.6084/m9.figshare.7429043) \\
Data file 3 [9] & Expression levels of SdsR and to/C & PDF & Figshare (https://doi.org/10.6084/m9.figshare.7429034) \\
Data file 4 [10] & Raw data used to generate graph in data file 3 & XLSX & Figshare (https://doi.org/10.6084/m9.figshare.7483538) \\
Data file 5 [11] & Growth curve of different mutants & PDF & Figshare (https://doi.org/10.6084/m9.figshare.7429037) \\
Data file 6 [12] & Raw data used to generate graphs in data file 5 & XLSX & Figshare (https://doi.org/10.6084/m9.figshare.7483562) \\
\hline
\end{tabular}

single-stranded loop region of SdsR. The native SdsR and artificially-designed SdsRv2 were overexpressed using the arabinose-inducible promoter system (Table 1, Data file 2). Semi-quantitative real-time PCR confirmed overexpression of both SdsR and SdsRv2 relative to the control strain (Table 1, Data file 3 and Table 1, Data file 4). The expression of tolC decreased in SdsR and SdsRv2 mutants respectively. The minimum inhibitory concentration (MIC) of norfloxacin in wild-type, SdsR and SdsRv2 mutants were determined to be at $0.06 \mu \mathrm{g} / \mathrm{ml}$, $0.06 \mu \mathrm{g} / \mathrm{ml}$ and $0.09 \mu \mathrm{g} / \mathrm{ml}$ respectively. Since MIC only provides the endpoint measure but not information on growth kinetics, we monitored the growth curve of these mutants under two sub-inhibitory concentrations $(0.02 \mu \mathrm{g} / \mathrm{ml}$ and $0.04 \mu \mathrm{g} / \mathrm{ml})$ of norfloxacin. The SdsR and SdsRv2 mutants showed improved growth compared to the wild-type in the presence of $0.04 \mu \mathrm{g} / \mathrm{ml}$ norfloxacin (Table 1, Data file 5 and Table 1, Data file 6). The SdsRv2 mutant which have higher predicted binding stability to tolC mRNA showed the highest growth rate compared to other strains. To our knowledge, this is the first report to show that although tolC mRNA was down-regulated by SdsR and SdsRv2, the sensitivity against norfloxacin decreased in S. sonnei.

\section{Limitations}

The shortcomings of this paper that prevented the data to be published in a regular paper are:

- SdsRv2 was tested in an S. sonnei strain that still maintains the wild-type copy of the SdsR. Although SdsRv2 should be able to compete with native SdsR for binding to its targets, the sole effect of SdsRv2 cannot be clearly defined when both species of RNA are present in a single cell.

- The effect of SdsR on antibiotics resistance in $S$. sonnei contradicts the phenotype observed in E. coli. Elucidation of the mechanism behind this phenotype requires further study, which is beyond the scope of this project. For example, a transla- tional fusion of the tolC UTR (untranslated region) to a reporter gene can be used to establish SdsR regulation. Nevertheless, this study presented an interesting contradictory result. The results from this project are being considered by the authors for future research to elucidate the reason for such discrepancy.

Abbreviations

SRNA: small RNA; MIC: minimum inhibitory concentration.

Authors' contributions

THS designed the experiment. GIN performed the experiments. THS and GIN wrote the manuscript. Both authors read and approved the final manuscript.

\section{Author details}

${ }^{1}$ School of Science, Monash University Malaysia, Jalan Lagoon Selatan, 47500 Subang Jaya, Selangor, Malaysia. ${ }^{2}$ Tropical Medicine \& Biology Multidisciplinary Platform, Monash University Malaysia, Jalan Lagoon Selatan, 47500 Subang Jaya, Selangor, Malaysia.

\section{Acknowledgements}

We thank Associate Professor Kumaran Narayanan for sharing the pBAD24 plasmid backbone.

\section{Competing interests}

The authors declare that they have no competing interests.

\section{Availability of data materials}

The data described in this Data note can be freely and openly accessed on Figshare (https://doi.org/10.6084/m9.figshare.7647194). Please see Table 1 and reference list for details and links to the data.

\section{Consent for publication}

Not applicable.

\section{Ethics approval and consent to participate} Not applicable.

\section{Funding}

This work was funded by the Monash University Malaysia third year research project grant and Tropical Medicine \& Biology (TMB) multidisciplinary platform seed grant. The funding bodies do not participate in the design of the study, analysis of the data and writing of the manuscript.

\section{Publisher's Note}

Springer Nature remains neutral with regard to jurisdictional claims in published maps and institutional affiliations. 
Received: 6 December 2018 Accepted: 9 February 2019

Published online: 21 February 2019

\section{References}

1. Ram PK, Crump JA, Gupta SK, Miller MA, Mintz ED. Part II. Analysis of data gaps pertaining to Shigella infections in low and medium human development index countries, 1984-2005. Epidemiol Infect. 2008;136(5):577-603.

2. Drlica K, Zhao X. DNA gyrase, topoisomerase IV, and the 4-quinolones. Microbiol Mol Biol Rev MMBR. 1997;61(3):377-92.

3. Waters LS, Storz G. Regulatory RNAs in bacteria. Cell. 2009;136(4):615-28.

4. Parker A, Gottesman S. Small RNA regulation of TolC, the outer membrane component of bacterial multidrug transporters. J Bacteriol. 2016;198(7):1101-13.

5. Kim T, Bak G, Lee J, Kim KS. Systematic analysis of the role of bacterial $\mathrm{Hfq}$-interacting sRNAs in the response to antibiotics. J Antimicrobial Chemother. 2015;70(6):1659-68.
6. Connor TR, Barker CR, Baker KS, Weill FX, Talukder KA, Smith AM, et al. Species-wide whole genome sequencing reveals historical global spread and recent local persistence in Shigella flexneri. eLife. 2015;4:e07335.

\section{Data citation}

7. Gan I-N, Tan HS. FigShare. 2019. https://doi.org/10.6084/m9.figsh are.7429040

8. Gan I-N, Tan HS. FigShare. 2019. https://doi.org/10.6084/m9.figsh are.7429043.

9. Gan I-N, Tan HS. FigShare. 2019. https://doi.org/10.6084/m9.figsh are.7429034.

10. Gan I-N, Tan HS. FigShare. 2019. https://doi.org/10.6084/m9.figsh are.7483538.

11. Gan I-N, Tan HS. FigShare. 2019. https://doi.org/10.6084/m9.figsh are.7429037.

12. Gan I-N, Tan HS. FigShare. 2019. https://doi.org/10.6084/m9.figsh are.7483562.
Ready to submit your research? Choose BMC and benefit from:

- fast, convenient online submission

- thorough peer review by experienced researchers in your field

- rapid publication on acceptance

- support for research data, including large and complex data types

- gold Open Access which fosters wider collaboration and increased citations

- maximum visibility for your research: over $100 \mathrm{M}$ website views per year

At $\mathrm{BMC}$, research is always in progress.

Learn more biomedcentral.com/submissions 